\title{
The Nature of the Relationship Between Corporate Identity and Corporate Sustainability: Evidence from The Retail Industry
}

\author{
Cláudia Simões \\ University of Minho
}

\section{Roberta Sebastiani}

Catholic University of Sacred Heart

\begin{abstract}
This article addresses the nature of the interface between corporate sustainability and corporate identity at both the strategic and instrumental levels. We developed an empirical qualitative study in two countries in Southern Europe addressing retailers who are actively engaged in pursuing corporate-sustainability strategies. Data sources include in-depth interviews, observations, and physical artifacts of identity (digital and printed documents). Findings reveal that, at a strategic level, corporate sustainability is embedded in corporate identity reflecting the company's strategy. Companies also instrumentally use corporate identity to operationalize corporate sustainability strategies. Organizations show different patterns in the way they bridge corporate sustainability and identity. The contributions of this article are threefold: it reports the symbiotic relationship between corporate sustainability and corporate identity; it scrutinizes how corporate sustainability and corporate identity are integrated at the strategic and operational levels; and it establishes distinct patterns at the interface of corporate sustainability and corporate identity.
\end{abstract}

KEY WORDS: corporate sustainability, corporate identity, strategy, sustainability performance

\footnotetext{
Current business environments bring new challenges for organizations and their long-term survival. For example, the economic downturn in certain geographical areas, such as Southern Europe (in particular within the Eurozone countries) has stimulated a debate on ethical ways and forms of looking at society and the economy as a whole (Lubin \& Esty, 2010; Skouloudis, Chymis, Allan, \& Evangelinos, 2014). In this context, sustainability has emerged as a relevant route for both political systems and organizations (Berns et al., 2009; Whelan, 2012) that aim to establish long-term and responsible forms of (new) capitalism. The sustainable development model takes into account the needs of present and future generations and is grounded on a balanced wealth distribution and access to resources (WCED, 1987). Yet, sustainable
} 
development cannot be pursued without the active involvement of companies and organizations that have the resources, skills, and motivation to engage in more sustainable societies (Bansal, 2002; Lozano, 2013). Following such direction, the notion of corporate sustainability has gained relevance as a business approach and as a foundation for the business model. Corporate sustainability denotes the voluntary "inclusion of social and environmental concerns in business operations and in interactions with stakeholders" (van Marrewijk, 2003: 102). Corporate sustainability further entails a long-term and, ultimately, endless perspective (Hahn, Pinkse, Preuss, \& Figge, 2015; Kiron et al., 2015). In its genesis and implementation, such a business approach involves an organization-wide reach and commitment, suggesting the need for the development of consistent behavior and supportive organizational culture.

Other concepts also note the related idea of the need for an organization-wide focus and a holistic view of the organization and its wider role in society. The overarching notion of corporate identity conveys the idea that every organization is a singular entity (Simões, Dibb, \& Fisk, 2005) that has its own personality. Corporate identity evokes the uniqueness of a company and reflects an integrated corporate posture that is portrayed in coherent behaviors and instruments (Ingenhoff \& Fuhrer, 2010). Corporate identity has strategic and instrumental roles in organizations. At the strategic level, corporate identity is the way companies define themselves and what makes them unique (He \& Balmer, 2013). At the instrumental level, corporate identity may be used as a managerial tool to operationalize, articulate, and convey the organization's identity and, ultimately, to express behavior (Simões et al., 2005; Simões \& Mason, 2012).

In this study we investigate the interface and relationship between corporate sustainability and corporate identity. This is a timely topic as ethical identity is an increasingly relevant feature of corporate activity requiring further understanding of its foundations and nature (Balmer, Fukukawa, \& Gray, 2007). At a corporate level, there is the need to search for the alignment between the interests of various stakeholders and the pursuit of sustainable and ethical concerns. Corporate identity may be a relevant foundation for building strong and beneficial relationships among stakeholders (Balmer, Powell, \& Greyser, 2011) and for articulating sustainability strategies and practices. Ultimately, companies that present a strong corporatesustainability profile attain higher business, social, and environmental performance.

Despite the relevance of the connection between the concepts of corporate sustainability and corporate identity, the nature of their relationship has not been comprehensively addressed in research. The sparse research on the connections between corporate sustainability (or related constructs, such as, corporate social responsibility) and corporate identity tends to focus on specific perspectives and/or contexts. For example, studies that investigate how particular corporate sustainability practices are related to corporate identity take an external engagement/ expression perspective, such as looking at buyer-supplier relationships (Bendinxen \& Abratt, 2007) and corporate websites (Bravo, Matute, \& Pina, 2012; Fatma \& Rahman, 2014). From an internal viewpoint, existing studies highlight the internal implementation of equal opportunity policies (e.g., Lauring \& Thomsen, 2009) or issues of internal and external legitimacy in building employee commitment and 
supporting corporate-sustainability programs (Frandsen, Morsing, \& Vallentin, 2013). Internal viewpoint studies often assume that sustainability per se motivates and commits organizational members (Morsing, 2009). Related research also addresses the links between sustainability and managerial functions, such as, marketing. For example, studies look at sustainability as a form of brand differentiation (Gupta, Czinkota, \& Melewar, 2013), or develop frameworks that include sustainability dimensions, corporate culture, and the incorporation of sustainable initiatives in brands as a route towards superior performance (Gupta \& Kumar, 2013; Kumar \& Christodoulopoulou, 2014). Although existing research shares relevant insights into the connections between corporate sustainability and corporate identity, further theoretical and empirical insights (Arnold, 2015) are needed to capture the nature of their relationship in a more comprehensive way. In addition, the role of cultural and behavioral dimensions in the organizational adoption of sustainability is still under-researched, and insights on the interface between corporate sustainability and identity may help us better understand the practices of sustainability.

In this article we analyze the levels of corporate sustainability management (strategic and operational) and how organizations might use corporate identity as a platform for the development and implementation of a sustainability-oriented identity. The focus of this study is internal, from the organization's perspective. The expected contribution is threefold. First, it will lend to an understanding of the interface between corporate sustainability and corporate identity, from an identity formation perspective. As sustainability becomes rooted in corporate identity, the nature of this connection is not yet fully understood. Second, as corporate sustainability is embedded in business practices and behaviors, it is expected that a sustainable identity becomes a pervasive stream within the organization framing employees' behaviors and the organization's culture. We shed light on the strategic and operational levels that corporate sustainability and corporate identity might connect. Third, we analyze the managerial challenges and tensions that are derived from the alignment of corporate sustainability and identity. We developed an empirical qualitative study based on four retailers in two countries in Southern Europe that are actively engaged in pursuing strategies for corporate sustainability. The research setting was relevant as the retailers' position in the supply chain involves a wide range of stakeholder interactions, including important sustainability issues that are open for investigation (Bartels, Reinders, \& Van Haaster-De Winter, 2015; Wiese, Kellner, Lietke, Toporowski, \& Zielke, 2012).

\section{CORPORATE SUSTAINABILITY}

Although there is no universal perspective on the notion of corporate sustainability (Amini \& Bienstock, 2014; Maletič, Maletič, Dahlgaard, Dahlgaard-Park, \& Gomišček, 2014), according to Hahn et al. (2015: 299), corporate sustainability "refers to a set of systematic interconnected and interdependent economic, environmental and social concerns at different levels that firms are expected to address simultaneously." Sustainability requires the effective integration of social and environmental issues into the vision, values, culture, and operations of the organization 
(Ahern, 2015). Building on this perspective, corporate sustainability can be interpreted as an overarching approach in which "ethical belief systems will converge to limit the moral 'free space' of organizations" (Gladwin, Kennelly, \& Krause, 1995: 897). An effective path to sustainability is primarily driven by the development of an ethically-based company culture with a focus on human resources, rather than being driven by company size or type of market offer (Sebastiani, Corsaro, Montagnini, \& Caruana, 2014). The adoption of holistic thinking in developing an ethical and sustainable corporate culture is relevant because an overarching posture acts as a platform that supports stakeholder engagement, organizational learning, and corporate-sustainability monitoring and control systems (Crews, 2010; Frandsen, Morsing, \& Vallentin, 2013). Corporate sustainability further implies a multifiduciary stakeholder ethic that challenges the primacy of shareholder profitability (Ahern, 2015).

Research on sustainability has addressed how structures, processes, and techniques may be used to ensure the effective integration of sustainability into managerial and employee practices (e.g., Amini \& Bienstock, 2014; Baumgartner, 2014). In particular, the managerial pursuit of corporate sustainability implies a focus on four key dimensions: societal, environmental, organizational culture, and economic. Societal influence gauges the mutual impact between society and the corporation, the social contract, and stakeholder influence. Environmental impact addresses the effect of the organization's actions on the geophysical environment. Organizational culture captures all aspects of the relationship between the organization and its internal stakeholders, in particular employees. The economic dimension refers to the attainment of a suitable return derived from financial risk management (Aras \& Crowther, 2008).

\section{Management Levels of Corporate Sustainability}

Managing corporate sustainability is a multifaceted and multi-level effort that combines the integration of strategies and resources at different levels in the organization. Baumgardner (2014) distinguishes between three levels of corporate sustainability management: normative, strategic, and operational. The normative management level aims at ensuring and enhancing the legitimacy of corporate activities that are conducted by internal and external stakeholders, and society, in general. The strategic management level uses sustainability strategies to pursue long-term effectiveness. For example, inward-looking sustainability strategies focus on risk mitigation by fulfilling legal and other external standards; outward-looking sustainability strategies highlight external relationships; conservative sustainability strategies center on eco-efficiency; and visionary sustainability strategies entail holistic approaches that concentrate on sustainability issues within all business areas and activities. The operational management level aims at attaining operational efficiency, within all corporate activities, when realizing strategic goals.

When operationalizing sustainability strategies (operational level), managers focus on the key dimensions that aim to enhance the effectiveness of corporate sustainability (Baumgartner \& Ebner, 2010): drivers, coordination, and implementation 
practices (Frandsen, Morsing, \& Vallentin, 2013; Schneider, Wallenburg, \& Fabel, 2014). The drivers for the implementation of corporate sustainability strategies are relevant as they are related to managerial outcomes. By implementing such strategies, organizations seek legitimacy, that is, to be perceived by all stakeholders as "desirable, proper, or appropriate within some socially constructed system of norms, values, beliefs, and definitions" (Suchman, 1995: 574). There is the expectation of market success through consumer patronage and investor decisions as a reward for the company's engagement in sustainability (Dunphy, Griffiths, \& Benn, 2007). There is also the prospect of improving and optimizing the company's internal processes through the development of sustainable practices that lead to cost savings. Companies might assign different weights to the relevance of these drivers (Windolph, Harms, \& Schaltegger, 2014).

Sustainability is a cross-functional 'stream' that implies the coordination of heterogeneous actors at different levels of the organization (Powell, 2011; Schneider et al., 2014). The generation of inter-functional coordination and synchronization among actors (Quinn \& Dalton, 2009) highlights developing coordination systems that range from mechanistic coordination (formalized and rather rigidly enforced processes and centralized hierarchical directives) to organic coordination (participative, organic, and loosely coupled structures with decentralized decision-making) (Olson, Walker, \& Ruekert, 1995).

Implementation practices of corporate sustainability ought to be consistent when translating the sustainability strategy into action. Companies may adopt soft and/ or hard practices. Soft practices are used to inspire employees' passion for and commitment to sustainability, and to generate identification with the organization's sustainability issues. Soft practices embrace dimensions related to the following aspects: "structure and culture fit, power and influence fit, communication, commitment, encouragement, and support" (Saunders, Mann, \& Smith, 2008: 1104). Hard practices consist of formal implementation systems that are used to signal sustainability dimensions within the organization. Hard practices aim to organize and manage information, and monitor and control sustainability through procedures, routines, systems, and structures (Hussey, 2007). Control is established through key performance indicators related to economic, social, and environmental performance. Examples of economic performance indicators contain company turnover, profit, product sales, and the organization's economic impact on society (etc.). Social performance indicators include labor practices, human rights, training and education, and broader issues that affect consumers, the community, and other stakeholders. Environmental performance indicators entail, for example, greenhouse gas emissions, water consumption, and waste output (Erol, Cakar, Erel, \& Ramazan, 2009).

\section{CORPORATE IDENTITY}

Corporate identity embodies the unique approach that organizations take towards their existence, business, behaviors (Bendixen \& Abratt, 2007), and engagement in the wider business context. Corporate identity is at the genesis of creating a sense of individuality and the features that distinguish the organization among various 
audiences (Simões et al., 2005). Corporate identity "is what helps an organization, or part of it, feel that it truly exists and that it is a coherent and unique being, with a history and a place of its own, different from others" (Kapeferer, 1996: 919). There are multiple, interdisciplinary insights into the notion of corporate identity and its management (Simões et al., 2005). The perspective related to graphic design and visual identity considers all forms of visual and physical presentation of the organization, such as corporate symbols (e.g., logos and signage) (Melewar \& Saunders, 1999; Olins, 1991; Pilditch, 1970), and sensory dimensions (e.g., auditory and olfactory features) (Bartholmé \& Melewar, 2009; 2011). Organization studies examine members' feelings towards their organization (Dutton, Dukerich, \& Harquail, 1994; Hatch, \& Schultz, 1997), and articulate the notion of organizational identity as what is central (i.e., the character), enduring, and distinctive about an organization (Albert \& Whetten, 1985). Marketing contributes to the field of corporate identity through related studies on brand management and integrated communications (e.g., De Chernatony, 1999; Riel, 1995). A stream of work in marketing focuses on the umbrella notion of corporate marketing and considers related concepts, such as, corporate identity, corporate brand, and corporate reputation (Powell, 2011).

We adopt a comprehensive and interdisciplinary perspective of corporate identity. The construct is foundational, entailing the definition and acknowledgement of the organization's philosophy, sense of purpose, and core values. Although identity evolves over time, it establishes the motives for the company's existence and defines the tone of the way to do business (Simões et al., 2005). Corporate identity involves what is intrinsic and unique about the organization, is embedded throughout the organization, and is reflected in its mission, values, and beliefs (Simões \& Mason, 2012). Pertaining to the notion of corporate identity is the multiple stakeholder perspective. Organizations need to present themselves to relevant stakeholders with consistent messages and behaviours. From an internal viewpoint, corporate identity is liquid in nature and pervasive throughout the organization mirrored in the shared values and beliefs. Corporate identity becomes embedded in the corporate culture and is consubstantiated in the shared behaviors of internal stakeholders. The concept of corporate identity also entails visual features and identity symbols that form the organization's identity (Olins, 1991). All of these factors should be attuned to the company's values and philosophy, and ought to be transmitted and understood by both internal and external stakeholders.

\section{The Dual Role of Corporate Identity: Strategic and Instrumental}

There are expectations that a strong corporate identity includes features that help an organization define and express its being. Corporate identity plays two general roles for organizations: strategic (part of strategy) and instrumental (implementation and a coherent expression of the organization). Marwick and Fill (1997: 401) note that corporate identity "forms a pivotal role which can influence the strategy content as well as providing a corporate communication system to stakeholders." According to Abratt and Kleyn's (2012: 1051) framework, corporate identity entails the "organization's strategic choices" and its "expression." Strategic choices involve such 
aspects as "mission, vision, strategic intent, values, and corporate culture" (1051) along with strategy formulation and strategy implementation. Corporate expression links corporate identity to constructs, such as visual identity, brand promise, brand personality, and brand communication (1050).

In its genesis and development, corporate identity integrates and/or is a function of the company's strategy. A holistic formulation of corporate identity entails the articulation and focus of the corporation's ethos and sense of individuality (Riel \& Balmer, 1997). One of the initial steps in the process of creating an identity is the delineation of the corporate philosophy that directs the organization's "way of being" through the mission, values, and beliefs (Balmer, Fukukawa, \& Gray, 2007). At this level, companies may use corporate symbols (e.g., corporate logos) to represent the identity position (Foroudi, Melewar, \& Gupta, 2014; Olins, 1991). The interface between corporate identity and strategy is interdependent and dynamic. Pertaining to such interface is the mutual influence and reliance between corporate identity and strategy. Corporate identity becomes the strategy driver/facilitator and strategy reinforces/shapes corporate identity. Corporate identity and strategy are also perceived to be mutually reliant as they serve as an intertwined reference for the organization's sensemaking (He \& Balmer, 2013).

The instrumental role of corporate identity captures the idea that identity can be used for strategy implementation/operationalization and as an expression of the organization's being. The expression is articulated through the organization's principles and behaviors, and visuals and tangible forms (Schmidt, 1995). Parts of identity can be managed, and, to a certain extent, shaped, in order to attain the desired identity expression (Simões et al., 2005; Simões \& Mason, 2012). Corporate identity may be transmitted through visual identity systems, communication (all forms of communication), and behavior (aspects of corporate behavior and culture) (Karaosmanoglu \& Melewar, 2006; Melewar \& Karaosmanoglu, 2006; Riel, 1995; Riel \& Balmer, 1997). Simões et al. (2005) suggest that the internal management of corporate identity (at the business unit level) should entail: "(1) the endorsement of consistent behavior through the diffusion of a company's mission, values, and goals; (2) the expression and pursuit of brand and image consistency in the organization's symbols and forms of communication; and (3) the implementation, support, and maintenance of visual systems" (153). Following these perspectives, the implementation and expression of corporate identity involves three over-arching dimensions: internal mission and values dissemination, consistency in all forms of communication, and the articulation of visual systems.

\section{ALIGNING CORPORATE IDENTITY AND CORPORATE SUSTAINABILITY}

Corporate sustainability represents an important opportunity for companies that are able to creatively interpret market dynamics (Lubin \& Esty, 2010). Sustainability dimensions, corporate culture, and the incorporation of sustainable initiatives in brands may constitute a route for superior performance (Gupta \& Kumar, 2013; Kumar \& Christodoulopoulou, 2014) and brand differentiation (Gupta et al., 2013). Yet, in their quest for sustainability, companies encounter complex challenges 
in managing and developing a meaningful differentiation from competitors (Kumar \& Christodoulopoulou, 2014). We propose bridging the concepts of corporate sustainability and corporate identity in order to understand how they may be related and intertwined within companies' practices. There is the need to search for congruency among

stakeholders, employees and to societal concerns and CSR/ethical concerns . . . . This is coupled with the realization that corporations (corporate identities) and institutional brands (corporate brand identities) provide meaningful identity platforms on which mutually beneficial corporate-stakeholder relationships are built (Balmer, 2011: 1333).

Ultimately, such endeavors would lead to differentiation among stakeholders and the establishment of long-lasting and positive associations with the company (i.e., the development of a strong corporate reputation) (Sarstedt, Wilczynski, \& Melewar, 2013; Weiss, Anderson, \& MacInnis, 1999).

Corporate identity plays strategic and operational roles by articulating organizations' sustainability directions, harmonizing the organizational culture, and serving as an instrument for the communication and implementation of corporate strategy (Abratt \& Kleyn, 2012). Corporate identity may be strategic in the organization's ethical alignment (Powell, 2011). Organizations may naturally include sustainability features in their identity by grounding their behaviors in sustainability principles (Berrone, Surroca, \& Tribó, 2007; Fatma \& Rahman, 2014). As Berrone, Surroca, and Tribó (2007: 36) note, “a firm’s ethical stance (i.e., its ethical values, behaviors, and communications on ethical commitments) can be seen as a component of the firm's corporate identity that may enhance corporate performance." Corporate identity may also play an instrumental role in the operationalization and communication of sustainability strategies. For example, corporate identity may assist in the implementation of sustainability strategies and practices through the organization's communicated identity, reliable behaviors (Bravo, Matute, \& Pina, 2012), and ethical initiatives (Atakan \& Eker, 2007; Berrone, Surroca, \& Tribó, 2007). These connections are shown on Figure 1.

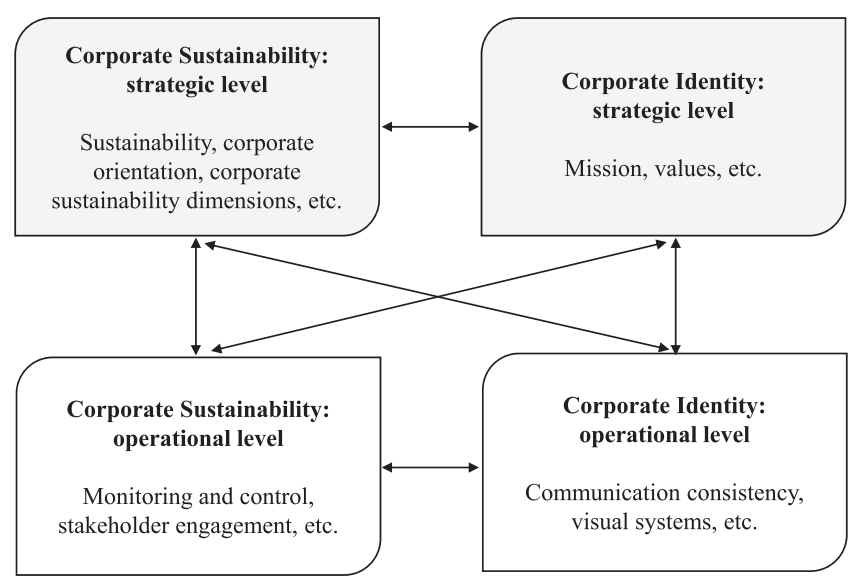

Figure 1: Connecting Corporate Sustainability and Corporate Identity 


\section{RESEARCH DESIGN}

In order to gain in-depth insights into the nature of the relationship between corporate sustainability and corporate identity, we developed a qualitative design using multiple data sources. We studied supermarket retailers and their approaches to corporate sustainability and identity. Retailers constituted a relevant setting for this research because they engage in different approaches to sustainability issues (Wagner, Bicen, \& Hall, 2008). Among companies that engage in the "sustainabilitization" process, retailers are moving towards "sustainable" managerial practices, shifting from a "control" perspective to a "values" oriented perspective (Pruzan, 1998). By being positioned at the end of the supply chain (Ytterhus, Amestad, \& Lothe, 1999), the retail industry is increasingly pivotal in the sustainability route through actively promoting sustainability within the community and introducing sustainability initiatives along the supply chain (Erol et al., 2009; Lozano, 2007). When retailers develop sustainable-orientated practices (e.g., development of new products/packaging, HR strategies, procurement, production, distribution approaches), they have a direct influence on the supply chain. From a demand perspective, retailers engender and articulate consumers' positive sustainable attitudes and behaviors. Other relevant background factors include the district features and the spatially disaggregated and dispersed nature of operations (Lynch, 1999). In supermarket retailers, contact among the company, employees, and customers occurs in the same physical environment (e.g., shops and stores), making the consideration of strategic and operational levels of sustainability particularly relevant (Bartels et al., 2015).

The fieldwork took place in two countries in Southern Europe, where an economic recession imposed particular strains on businesses highlighting their sustainability role (Berns et al., 2009; Skouloudis et al., 2014). Such context allowed us to detect how retailers embrace sustainability in their identity and how they disseminate and practice sustainability. The data was collected in four retail supermarket chains that presented strong sustainability concerns in their communication strategies. Retailers differed in their approaches to sustainability and were varied in size and growth strategies. Such variability was fundamental to capturing the different ways in which sustainability could relate to corporate identity. The data collection provided perspectives from multiple sources, informants, and contexts. Data sources involved in-depth interviews, observation, and physical artifacts of identity that included digital and printed documents. The data focused on corporate information and/or information about the parent company addressing sustainability. Table 1 summarizes the data collection details.

Key informants included top and middle level managers and employees who worked for the retailers. The range of informants captured the intended strategic and operational aspects related to the link between corporate sustainability and corporate identity, and their consistency across different levels within the organization. For example, we learned from (sustainability) managers about the (non)intended alignment between corporate identity and sustainability and its implementation at the operational level. Interviewing frontline employees allowed us to understand the levels of communication and operationalization involved in sustainability strategies. 
Table 1: Data Collection

\begin{tabular}{|c|c|c|c|}
\hline Retailer & Demographics & Collected data & Interviewees \\
\hline R1 & $\begin{array}{l}\text { International chain } \\
\text { Present in } 16 \text { countries in Europe, } \\
\text { Asia, and rest of the world. } \\
\text { Over } 300,000 \text { employees } \\
\text { Over } 960 \text { hypermarkets and } \\
2800 \text { supermarkets worldwide } \\
\text { Food retailer (hypermarkets and } \\
\text { supermarkets) }\end{array}$ & $\begin{array}{l}\text { Interviews } \\
\text { Digital and printed } \\
\text { documents } \\
\text { Observation in two } \\
\text { countries }\end{array}$ & $\begin{array}{l}1 \text { general manager } \\
1 \text { CSR manager; } 1 \text { director of } \\
\text { internal communication and } \\
\text { social responsibility* } \\
1 \text { corporate communications } \\
\text { manager; } 1 \text { marketing manager } \\
2 \text { HR directors* } \\
1 \text { senior buyer } \\
1 \text { regional manager } \\
3 \text { shop managers; } 4 \text { shop walkers; } \\
3 \text { cashiers }\end{array}$ \\
\hline $\mathbf{R} 2$ & $\begin{array}{l}\text { Leading national chain } \\
\text { Largest retail chain in the country } \\
\text { Over } 56,000 \text { employees } \\
100 \text { hypermarkets and over } \\
1400 \text { supermarkets, convenience, } \\
\text { and discount stores } \\
\text { Food retailer (hypermarkets and } \\
\text { supermarkets) }\end{array}$ & $\begin{array}{l}\text { Interviews } \\
\text { Digital and printed } \\
\text { documents } \\
\text { Observation }\end{array}$ & $\begin{array}{l}1 \mathrm{CS} \text { innovation and values } \\
\text { manager } \\
1 \text { private label manager } \\
1 \text { corporate communications } \\
\text { manager } \\
3 \text { shop managers } \\
4 \text { sales clerks; } 3 \text { shop walkers; } \\
4 \text { cashiers }\end{array}$ \\
\hline $\mathbf{R 3}$ & $\begin{array}{l}\text { International chain specialized } \\
\text { in sustainable products } \\
\text { Operating in two countries } \\
\text { Over } 900 \text { employees } \\
\text { Over } 200 \text { supermarkets } \\
\text { Food retailer (supermarkets) }\end{array}$ & $\begin{array}{l}\text { Interviews } \\
\text { Digital and printed } \\
\quad \text { documents } \\
\text { Observation }\end{array}$ & $\begin{array}{l}1 \text { general manager } \\
1 \text { corporate communication } \\
\text { manager } \\
4 \text { shop managers; } 6 \text { sales clerks; } \\
2 \text { cashiers }\end{array}$ \\
\hline R4 & $\begin{array}{l}\text { National venture specialized } \\
\text { in selling local food } \\
\text { About } 50 \text { employees } \\
\text { One food hall ( } 2000 \text { sq m) }\end{array}$ & $\begin{array}{l}\text { Interviews } \\
\text { Digital and printed } \\
\text { documents } \\
\text { Observation }\end{array}$ & $\begin{array}{l}1 \text { founder } \\
4 \text { producers }\end{array}$ \\
\hline
\end{tabular}

$\mathrm{CS}=$ corporate sustainability; $\mathrm{CSR}=$ corporate social responsibility.

* (One) interview undertaken in a different country

In total 55 interviews were conducted, and they were concluded when the theoretical saturation point was reached (Seale, Gobo, Gubrium, \& Silverman, 2004). Interviews took place on site, and were audio-recorded and translated to English. The data collected also included artifacts of corporate identity (e.g., company reports, websites, in-store layouts, colors, the presentation of symbols) that reflected corporate sustainability and its operationalization. We further recorded detailed field notes of our observations and visits to the companies and sites where the interviewees worked. The information gathered captured interviewees' descriptions and allowed for a review of the consistency in the interpretations and visibility of sustainability and identity in the organization's practices.

The questions in the interview guide explored the perceptions of key informants in relation to different corporate-identity dimensions and how corporate-sustainability issues were embedded or operationalized within those dimensions. In particular, the interview guide was grouped into the following themes: general information (e.g., main issues about corporate sustainability in the company; corporate-sustainability 
management and internal communication); mission and values (e.g., what is the mission of the company; how does the mission reflect corporate sustainability); visual identity (e.g., the extent to which symbols reflect the corporate sustainability strategy and how); and communication/image (e.g., the extent to which internal/ external communication reflects the corporate-sustainability strategy). The guide was discussed with three academics; after the initial set of interviews, it was refined to better capture the study objectives/concepts and achieve face validity. The interview guide was adjusted to the different key informants and their ability to respond to the questions.

The data analysis entailed inductive reasoning and comparative methods. A general data discussion between the researchers established the route for the analysis capturing the relevant aspects related to the research question. Emphasis was placed on a systematic examination of the transcripts, documents, and remaining data (Turner, 1981). The analysis of the interviews involved a thematic approach that is useful for theorizing across a number of cases. Themes were structured around patterns of information that allowed for organizing and describing the data so that our interpretations could be derived (Boyatzis, 1998). Thematic categories were supported by keywords, verbatim quotations from interviewees, and the remaining data collected. Initially, each code formed a potential category. As the coding progressed, new categories were created or merged according to the content of the data. Multiple data sources contributed to a broader and insightful understanding of the phenomenon under study supporting data triangulation. Because the data included interviews with multiple respondents and documents within the same retailer, it allowed testing the accuracy of the information obtained from key informants and the consistency and reliability of the collected data (Homburg, Klarmann, Reimann, \& Schilke, 2012). The final main themes were established after follow-up discussions with key informants and a panel of academic experts and practitioners. This procedure enhanced the reliability and validity of the findings.

\section{FINDINGS AND DISCUSSION}

The findings revealed the emergence of patterns in the connection between corporate sustainability and identity, showing how organizations can leverage the bridge between both dimensions. The data were organized into four main themes: 1) transforming corporate sustainability and corporate identity at the strategic level; 2) the instrumental role of corporate identity in operationalizing corporate sustainability; 3) (mis)aligning corporate sustainability and corporate identity; and 4) and managing corporate sustainability and corporate identity (mis)alignment.

\section{Transforming Corporate Sustainability and Corporate Identity at the Strategic Level}

To develop a corporate-sustainability orientation, organizations need to define the relevant strategies and establish an effective organization's culture. Leveraging the interconnection between corporate sustainability and corporate identity could help by reinforcing the whole organization's sustainability orientation and the uniqueness 
of its identity. Ultimately, such connection will have an impact on the organization's culture and behaviors. The mission and values play a key role in orienting the business strategies companies develop (Abratt \& Kleyn, 2012). Our findings support this idea, showing that the retailers' (in the study) mission and values are in alignment with sustainability issues. The corporate mission statements embedded clear, yet diverse sustainability content (Table 2). Explicit references to corporate sustainability range from an inclusive general statement (Retailer 1) to an articulated mission that highlights various issues related to corporate sustainability (Retailer 2). The corporate sustainability content may also be formalized and explicitly directed at different actors (Retailer 3 ) or be discursive and informally shared (Retailer 4). The scope of the corporate values varies across retailers. Retailers 1 and 2 present general sustainability values, such as, "sharing" (Retailer 1) and "solidarity" (Retailer 2). Retailer 3 mixes general sustainability values - "sustainable development" - with a more specific value that is related to the market offer - "healthy eating." Retailer 4

Table 2: Corporate Sustainability Reflection in Mission Statements, Values, and Corporate Symbols/Tangible Elements

\begin{tabular}{|c|c|c|c|}
\hline Retailer & Mission & Values & $\begin{array}{c}\text { Corporate symbols/ } \\
\text { tangible elements }\end{array}$ \\
\hline $\mathbf{R 1}$ & $\begin{array}{l}\text { To improve the purchasing power and quality of } \\
\text { life of the greatest number of customers, with } \\
\text { responsible, professional, committed, and } \\
\text { respectful employees. }\end{array}$ & $\begin{array}{l}\text { Trust } \\
\text { Sharing } \\
\text { Progress }\end{array}$ & Green areas \\
\hline $\mathbf{R 2}$ & $\begin{array}{l}\text { To fulfill the social function of protecting } \\
\text { (non)members' family budgets by providing } \\
\text { goods and services of good quality in the best } \\
\text { possible conditions. } \\
\text { To orient consumers towards purchasing the right } \\
\text { amount of products that offer greater guarantees } \\
\text { of quality/safety at the best price. } \\
\text { To develop the spirit of solidarity among consumer } \\
\text { members, their families and workers. } \\
\text { To protect the interests of consumers and their } \\
\text { health and safety by providing information and } \\
\text { education through sustainable initiatives. } \\
\text { To contribute to the protection of the environment. } \\
\text { To promote and enhance the development of } \\
\text { cooperation at the international level and to } \\
\text { assist developing countries through the } \\
\text { promotion of fair trade and the support of } \\
\text { disadvantaged groups. }\end{array}$ & $\begin{array}{l}\text { Sociability } \\
\text { Mutuality } \\
\text { Solidarity } \\
\text { Social justice }\end{array}$ & $\begin{array}{l}\text { Corporate logo } \\
\text { Private label }\end{array}$ \\
\hline $\mathbf{R 3}$ & $\begin{array}{l}\text { To support individuals in choosing the best } \\
\text { products for their well-being, and to convey } \\
\text { a healthy, responsible, and conscious food } \\
\text { culture. }\end{array}$ & $\begin{array}{l}\text { Healthy eating } \\
\text { Earth care } \\
\text { Sustainable } \\
\text { development }\end{array}$ & $\begin{array}{l}\text { Corporate symbol: } \\
\text { a ladybug }\end{array}$ \\
\hline R4 & $\begin{array}{l}\text { To improve and promote the local production } \\
\text { of excellent and traditional food, directly } \\
\text { from the producer to the consumer. } \\
\text { [Note: Producers are present in-store and sell } \\
\text { products directly to customers] }\end{array}$ & $\begin{array}{l}\text { Pleasure } \\
\text { Transparency } \\
\text { Knowledge } \\
\quad \text { sharing }\end{array}$ & Corporate logo \\
\hline
\end{tabular}


adds an experiential content (e.g., "pleasure") into its values. Additionally, corporate symbols and tangible elements with a corporate scope are used to symbolically capture the company identity. Symbols constitute a tangible dimension of identity and include, for example, the corporate logo. Closer scrutiny of Table 2 reveals relevant insights into the strategic connection between corporate sustainability and identity.

Companies ought to consistently frame corporate identity through leadership commitment and internal and external stakeholder engagement. When the mission's scope is relatively broad (e.g., Retailer 1) an internal issue of legitimacy emerges. Other mission statements attempt to capture the multidimensional nature of corporate sustainability (e.g., Retailer 2). Such wide scope or multidimensionality can be successfully integrated into the organization's strategy through an over-arching concept. The focus on a specific vector at the strategic level facilitates the incorporation of sustainability issues into corporate identity, especially when organizations try to adopt a true integrative approach to sustainability (Hahn et al., 2015). For instance, Retailer 1 developed the tangible element "green areas" to strengthen its competitive position through improvements in the efficiency of organizational processes and the mitigation of negative ecological impacts. The related symbol "green areas" inside the stores captures this position and represents efficient solutions for energy saving, recycling, and waste avoidance. These aspects were core to intertwining corporate sustainability and identity, as the organization is a complex and multi-level multinational corporation. Retailer 2 established the private label as core to the company's strategy. The private label is the platform around which the offering system is managed. It is a key tangible symbol of the corporate sustainability strategy creating awareness among store-level staff by translating into practice of the managerial mindset regarding sustainability and effectively influencing organizational culture and differentiation in the marketplace. As the manager of the private label explained: "The challenge is to translate our values into our strategies, with the primary aim of fulfilling the expectations of our customers in terms of value proposition. This is the key feature that distinguishes our company from our direct competitors" (private label manager, R2, interview).

When corporate sustainability becomes a salient aspect of corporate identity, coherent and holistic sustainability strategies develop more fluidly (Baumgartner \& Ebner, 2010). Retailer 4's business strategy aims to create a unique positioning in the market. As the company's founder stated: "Our basic aim, distinct from mainstream retailers, is to ensure that producers have the opportunity to be adequately remunerated for their work in order to let their children continue the tradition. Basically, we want to create jobs and improve the region" (founder, R4, interview). Retailer 3's corporate sustainability has been embedded in corporate identity since the company's founding. The founders take a proactive approach towards sustainability, anticipating changes at the environmental and societal levels. The company developed a differentiating strategy based on the continuous opening of new stores devoted to selling selected organic products and actively supporting the logic of a short food supply chain that directly involves strategic producers. As the general manager stated: "Organic food may be a business, but really relying on its values is another thing. And that's what makes the difference in terms of success" (general manager, R3, interview). 


\section{The Instrumental Role of Corporate Identity in Operationalizing Corporate Sustainability}

When addressing the operationalization of corporate-sustainability strategies, retailers showed a variety of ways to incorporate sustainability practices into corporate identity. Our findings suggest that organizations that implement corporate sustainability use the following corporate identity instruments: assortment, partner selection and purchasing practices, communication, visual identity support and store layout, community involvement and support activities (internal and external) (Table 3). Retailers present distinct patterns in their approaches to the assimilation of sustainability in corporate identity instruments that range from fragmented to integrated.

Retailers 1 and 2 present a fragmented and partial connection between corporate sustainability and identity. Retailer 1 competes through a wide range of products and introduces a few lines of sustainable products within a global assortment. A senior buyer notes, "Sometimes I am requested to select products with certain (sustainable) characteristics, but only for specific categories. For the other products, the specifications are the same as we have always used" (senior buyer, R1, interview). The retailer has clear sustainability codes and guidelines for its numerous suppliers and specific projects that involve sustainable architecture and solutions for energy, water, and waste management. Part of the store layout reflects a sustainability orientation (e.g., dedicated isles, or specific installations and solutions). Similarly, communication (e.g., media advertisements) is essentially tailored towards a marketing purpose. Retailer 1 also develops activities that extend its sustainability actions into the wider community. For example, employees are involved in training the general public on becoming "responsible citizens."

Retailer 2's product assortment consists of a wide range of products from which an increasing part is made from sustainable products (e.g., fair trade products). Partner selection has been increasingly strict. The aim is to create a stable network of partners committed to sustainability in order to strengthen the company's position in the market. Specific purchasing guidelines and an ethical code of conduct aim to support long-lasting relationships with suppliers. This initiative is under development. As one employee explained, "We have received several guidelines that we have to follow to select the suppliers but, at the moment, the commitment is not that strong. Sometimes we use them, especially with the new suppliers, while with the existing ones it is more difficult to apply" (buyer for R2, interview). To promote sustainability, both inside and outside the organization, the retailer resorts to a large number of in-store/external communication activities. The tone of communication is aimed at highlighting the advantages of sustainable behaviors, both at the individual and societal levels. These efforts are mirrored in education activities that are developed for employees and consumers. Retailer 2 also establishes contact with the local communities, where it conducts numerous activities that show the company's proclivity towards the social dimension of sustainability.

Retailers 3 and 4 present a comprehensive and integrated approach to connecting sustainability and identity at the operational level. Both retailers ensure their full product range is sustainable. Although such approach is more feasible when the 
Table 3: Corporate Sustainability Strategy Implementation as Reflected in Corporate-Identity Instruments

\begin{tabular}{|c|c|c|c|c|}
\hline & Retailer 1 & Retailer 2 & Retailer 3 & Retailer 4 \\
\hline Assortment & $\begin{array}{l}\text { Wide product range } \\
\text { Few specific lines of } \\
\text { sustainable products }\end{array}$ & $\begin{array}{l}\text { Wide product range } \\
\text { Own-label sustainability brand } \\
\text { Organic products } \\
\text { Fair trade products }\end{array}$ & $\begin{array}{l}\text { Limited assortment focused on organic } \\
\text { products }\end{array}$ & $\begin{array}{l}\text { Limited assortment related to } \\
\text { local food traditions }\end{array}$ \\
\hline $\begin{array}{l}\text { Partner selection } \\
\text { and purchasing } \\
\text { practices }\end{array}$ & $\begin{array}{l}\text { Purchasing guidelines } \\
\text { (International Product } \\
\text { Sourcing and Purchasing } \\
\text { Department) } \\
\text { Large number of providers } \\
\text { at local and global levels } \\
\text { Ethical code of conduct }\end{array}$ & $\begin{array}{l}\text { Sustainability related } \\
\text { purchasing guidelines } \\
\text { Careful selection of partners, } \\
\text { especially for own-label } \\
\text { products } \\
\text { Ethical code of conduct }\end{array}$ & $\begin{array}{l}\text { Careful selection of products and producers } \\
\text { International standard for organic and } \\
\text { biodynamic products and productions } \\
\text { Supporting organic products and producers } \\
\text { Ethical code of conduct }\end{array}$ & $\begin{array}{l}\text { Strict and limited selection of } \\
\text { suppliers } \\
\text { Suppliers as part of the business } \\
\text { model } \\
\text { Ethical code of conduct, based } \\
\text { on legal agreement and also } \\
\text { related to in-store activities }\end{array}$ \\
\hline Communication & $\begin{array}{l}\text { In-store communication } \\
\text { Sustainability report } \\
\text { Internet/media } \\
\text { In-house posters } \\
\text { Internal newsletter }\end{array}$ & $\begin{array}{l}\text { TV advertising } \\
\text { In-store communication } \\
\text { Sustainability report } \\
\text { Newsletter } \\
\text { Internet } \\
\text { Intranet }\end{array}$ & $\begin{array}{l}\text { Outdoors } \\
\text { In-store communication } \\
\text { Newsletter } \\
\text { Internet }\end{array}$ & $\begin{array}{l}\text { Storytelling on production } \\
\quad \text { processes } \\
\text { In-store demonstrations } \\
\text { In-store communication } \\
\text { Local newspapers }\end{array}$ \\
\hline
\end{tabular}


Table 3: continued

\begin{tabular}{|c|c|c|c|c|}
\hline & Retailer 1 & Retailer 2 & Retailer 3 & Retailer 4 \\
\hline $\begin{array}{r}\text { Visual identity } \\
\text { support and } \\
\text { store layout }\end{array}$ & $\begin{array}{l}\text { Eco-friendly store format } \\
\text { Energy, water, and waste } \\
\text { management } \\
\text { Carbon-footprint reduction } \\
\text { Canisters for unpackaged } \\
\text { goods } \\
\text { Green stalls } \\
\text { Shopping cart made with } \\
\text { recycled plastic }\end{array}$ & $\begin{array}{l}\text { Sustainable architecture } \\
\text { Wood-chip heating } \\
\text { Heat pumps and district heating } \\
\text { Use of biogas plants } \\
\text { Photovoltaic systems } \\
\text { Green stalls } \\
\text { Recovery systems for water } \\
\text { and heat } \\
\text { Carbon footprint reduction } \\
\text { Prevention, recycling, and } \\
\text { waste disposal }\end{array}$ & $\begin{array}{l}\text { General lighting systems with energy } \\
\text { saving lamps } \\
\text { Reduction of packaging and waste } \\
\text { Reduction of carbon dioxide emissions } \\
\text { Stalls made with natural or recyclable } \\
\text { materials } \\
\text { Promotional material and newsletter } \\
\text { made with } 100 \% \text { recycled paper } \\
\text { Interiors painted with natural colors, made } \\
\text { with raw materials of natural origin, } \\
\text { odorless, non-allergenic, non-toxic, highly } \\
\text { breathable, washable, and resistant to mold, } \\
\text { conforming to the strictest standards. }\end{array}$ & $\begin{array}{l}\text { Stalls made with natural or } \\
\text { recyclable materials } \\
\text { Areas dedicated to training } \\
\text { and interaction between } \\
\text { consumers and producers }\end{array}$ \\
\hline $\begin{array}{l}\text { Community } \\
\text { involvement } \\
\text { and support } \\
\text { activities } \\
\text { (internal and } \\
\text { external) }\end{array}$ & $\begin{array}{l}\text { Training sessions on } \\
\text { sustainable development } \\
\text { practices } \\
\text { E-learning program } \\
\text { "Employees and } \\
\text { Responsible Citizens" } \\
\text { Group foundations dedicated } \\
\text { to different causes (youth, } \\
\text { solidarity and social } \\
\text { integration, social } \\
\text { entrepreneurship }\end{array}$ & $\begin{array}{l}\text { Education activities for all } \\
\text { employees } \\
\text { Education in sustainable } \\
\text { consumption } \\
\text { Numerous projects developed } \\
\text { in partnership with local } \\
\text { communities } \\
\text { Active customer engagement } \\
\text { in defining sustainability } \\
\text { strategies }\end{array}$ & $\begin{array}{l}\text { Education activities for new employees } \\
\text { about producers and product features } \\
\text { Education activities and events targeting } \\
\text { customers } \\
\text { Active support of producers of organic } \\
\text { products } \\
\text { Initiatives aimed at local communities }\end{array}$ & $\begin{array}{l}\text { Weekly and monthly meetings } \\
\text { with partners and employees } \\
\text { Education activities and events } \\
\text { targeting customers } \\
\text { Active support of local } \\
\text { producers } \\
\text { Initiatives aimed at promoting } \\
\text { the region }\end{array}$ \\
\hline
\end{tabular}


retailer's offer entails a limited range of products, it contributes to effectively convey a unique corporate identity to stakeholders. The relationship with the suppliers also reflects this approach. The distinguishing features are the careful selection of partners and control of the relationship. Retailer 3 exerts clear control over the suppliers of its assortment of 4,000 food items, which are certified as "organic and natural foods." These products are produced in an environmentally friendly manner that respects nature, human health, and animal welfare. A carefully selected group of quality inspectors maintains control. Results of quality tests are made publically available in every shop, thereby keeping consumers informed and conveying transparency in company activities. Retailer 4 maintains control over its suppliers through a legal agreement that binds business partners to sustainable behaviors when developing in-store activities. Any breach of the agreement results in the exclusion of the supplier from the restricted group of business partners. Hence, the corporate sustainability orientation is reinforced as a corporate identity differentiator.

By being smaller and specialized, Retailers 3 and 4 are able to project a unique corporate identity through their communications and store layout. In addition to traditional means of communications, such as outdoor displays (Retailer 3), they also develop further initiatives to convey their sustainability orientation. For example, the store layout and in-store atmosphere make the employees and consumers feel that they are in a different setting compared to traditional supermarkets. The instruments used are wide-ranging. Retailer 3 conveys environmental quality through in-store fittings and green stalls. As a store manager explained, "The relaxed and quiet atmosphere, the low shelves that do not restrict the view, the colors, the kindness and expertise of the staff are acknowledged and appreciated" (store manager, R3, interview). Retailer 4 stages in-store production areas, making the production process visible to the public. For these retailers, community activities entail education initiatives that involve employees, customers, business partners, and the local community.

\section{3. (Mis)aligning Corporate Sustainability and Corporate Identity}

The previous discussion suggests that the way and the extent to which organizations integrate sustainability approaches and embed corporate sustainability within corporate identity varies at both the strategic and operational levels. The retailers in the sample showed distinct levels of integration and embeddedness of each construct, consequently, reaching different outcomes (e.g., resource integration, stronger image/reputation, differentiation, performance). The main challenges, highlighted by the managers, relate to the multi-dimensional nature of corporate sustainability and the lack of established models and methodologies that support its definition, development, and implementation. Findings further show the existence of challenges and tensions that arise at both the strategic and implementation levels.

\subsection{Challenges in Integrating Corporate Sustainability and Corporate Identity at the Strategic Level}

Friction may arise at the strategic level when there is a dominant, but not explicit, dimension of corporate sustainability in corporate identity, due to the organization's 
competitive position in the market. For example, often the economic pillar of sustainability reflects a prevailing feature in the development of the sustainability strategy. For large retailers, such as Retailers 1 and 2, the increasing competition they face strongly influences their way of addressing sustainability issues, whereby they primarily (and instrumentally) focus on the economic dimension of sustainability. In such situations, the integrative approach of all the three pillars of sustainability (Gao \& Bansal, 2013) is more difficult to attain, reinforcing the tension between business demands and social expectations (Hahn et al., 2015). The core identity of Retailer 2 was originally based on a strong orientation towards social sustainability. This has weakened overtime, as the retailer has grown in size to become the national market leader. Increased competition and an economic downturn have put severe pressure on profit margins. The company moved from a dominant social-orientation focus to a dominant economic orientation. As a consequence, when attempting to determine the retailer's different dimensions of sustainability, the emphasis was unclear. This lack of focus confuses employees, customers, and other stakeholders. The multifaceted and unclear mission disorients the targets and negatively impacts the strength of the corporate identity. Retailers 3 and 4 take a different position, wherein social and environmental concerns are more prominent. Although this combined orientation sustains a strong corporate differentiation, it weakens the organization's ability to successfully develop its business. An ethical and sustainable corporate identity that is strongly committed to social and environmental issues might limit the possibility of the organization being able to effectively contribute to sustainable development on a large scale. Such companies experience more difficulties in going mainstream and growing their businesses.

\subsection{Challenges in Integrating Corporate Sustainability and Corporate Identity at the Operational Level}

Developing a sustainability strategy implies making a cognitive change related to managerial mindsets. In view of the identified constraints, the translation of a strategy into practice becomes a challenge for companies that is amplified when their cultural norms are not aligned with the sustainability aspects causing inconsistencies in stakeholder's perceptions. Employees may not understand, accept, and follow the directions set out by management (Frandsen et al., 2013). These aspects relate to Berrone, Surroca, and Tribó's (2007) distinction between the communication of an organization's ethical attitudes and beliefs, (i.e., its corporate-revealed ethics) and the application of ethical behavior through actions and policies (i.e., its corporate-applied ethics). Key "soft" and "hard" practices articulate the translation of sustainability strategies into concrete and effective initiatives and behaviors, disseminating sustainability throughout the organization. When soft and hard practices are complementary, harmonization among the different practices and the internal coordination of the operational dimensions (Powell, 2011) becomes feasible. However, firms show different levels of integration. 
(Mis)alignment in Key Soft Practices

Key soft practices entail initiatives that are related to each other, such as communication, education, and engagement. Communication consistency aims at enhancing employees' (and other relevant stakeholders') consciousness about sustainability issues and enacting on the corporate mission through the corporate expression of identity using brand positioning. Our findings highlight that communication consistency is core to intertwining corporate sustainability and identity. In order to effectively align ethical and sustainable values (corporate identity) and behaviors (corporate sustainability ), communication tools and activities need to combine various methods, such as, consistently sharing values in internal and external communications, and sharing an articulated message about employees' expected behaviors. It is also important to go beyond the traditional one-way approaches and purely rational contents, for example, by using in-store demonstrations and storytelling about products and production. Retailer 2 took account of the customers and community in developing activities around the motto "Live better, pay less." The company develops in-store events that promote sustainable consumption and the experience of sustainable consumption practices. Storytelling is also a powerful means of communication in transmitting corporate sustainability because it promotes transparency. Retailer 4 tends to leverage this method in order to differentiate the company's corporate identity in an ethical and sustainable fashion. As one of Retailer 4's business partners explained, "Since we are always in the store and are part of the retail formula with our production area, we have the possibility to explain to the consumer the product, its origin, and its production process" (business partner, R4, interview).

There are challenges in attaining consistency when developing and communicating a high number of initiatives to numerous internal and external stakeholders. A clearer focus on the key messages and the tone of communication is required to successfully pursue corporate sustainability at different levels and to effectively implement a more ethical corporate identity. Fragmented and partial connections between the two constructs have a limited effect in the organization's cultural/ behavioral change towards sustainability and might generate confusion among employees. For example, Retailer 2 develops multiple heterogeneous communication activities related to different sustainability initiatives. Since there are several local coordinators for communication, employees perceive a lack of harmonization in the core message and its content. Efforts tend to be disparate and are not effective in spreading the company's sustainability orientation either within or outside the organization. In a sales clerk's words,

There are so many projects and activities, that we do not notice and do not even mention to customers, whom, like us, seem not to notice them. I have a feeling that sometimes the company lacks a clear and distinguishable commitment to the various initiatives that often overlap (sales clerk, R2, interview).

Similar tensions occur with Retailer 1. As a sales clerk explained,

I feel disappointed because I found out about a particular initiative, developed by my company, from the newspapers. When a customer asked me for further information 
about the initiative (a sort of virtuous recycling), I was not able to provide any additional information (sales clerk, R1, interview).

There ought to be active involvement of employees and business partners in order to more effectively integrate corporate sustainability and identity. The education dimension comprises initiatives, such as training sessions on sustainable development practices, education activities for (new) employees, and periodic meetings with business partners. Employees are often trained in order to better understand the philosophy of the retail chain and its offerings. Direct experience with the values behind the products reinforces this training. For example, employees may learn about the production processes to better understand the products' background enabling them to share corporate sustainability at cognitive and emotional levels. As a sales clerk of Retailer 3 explained, "When the customer is in the store, he relies on us for detailed information about the products and about the 'why and how' to consume them. I feel very satisfied with being involved in this process, even though my job in itself is not very exciting" (sales clerk, R3, interview). Notwithstanding the intense training and education programs, employees, especially the ones operating in-store, do not always feel that they work for a sustainable company. Big retailers tend to have formalized and standardized education programs that do not always consider the specificities of the different retail environments in which employees operate and their different perceptions about sustainability. This type of initiative is frequently seen as top-down and, if not managed properly, the ability to engage employees may be compromised. Although the strategic focus remains on corporate sustainability, the effort becomes weaker at the operational level. As a cashier from Retailer 1 stated,

I think that all these sustainability initiatives are mainly used for reducing costs, especially in-store solutions. I am not feeling that engaged with sustainability and neither are the customers, according to my experience. They prefer our store for other reasons. For example, because of proximity and convenience (cashier, R1, interview).

Organizational engagement and commitment are needed to attain alignment among employees (Rodrigo \& Arenas, 2008), other stakeholders, and corporate identity. Continuous sense-making and sense-giving are core managerial tasks related to the implementation of corporate sustainability (Frandsen et al., 2013) for all the actors involved in the process (in particular, employees). Actors should participate in the development of strategies and practices and engage in a permanent dialogue and debate about the sustainability dimension. The retailers in our study are trying to develop a real corporate-sustainability orientation and engagement by establishing internal processes and structures (e.g., cross-functional teams) aimed at encouraging dialogue and debate over how sustainability is interpreted and operationalized. This seems to produce effective results among smaller retailers (e.g., Retailer 4), where processes are more informal and dialogue is part of the corporate culture (see also, Frandsen et al., 2013). Yet, critique and skepticism are often neglected aspects in sustainability programs. This may result in individuals distancing themselves from the company's sustainability values and strategies and not identifying with the 
emergent corporate identity. Since Retailer 2 is an organization that is supposed to be sustainability oriented, managers expect employees to behave accordingly and, implicitly, to share the same commitment towards sustainability issues. Surprisingly, while customers of Retailer 2 are actively engaged in defining sustainability strategies and methods for implementation, employees are not involved in this process. They are trained on sustainability issues and initiatives, but in a passive way. As one sales clerk noted,

Nobody has asked my opinion in this regard or has discussed with me what I should do to be sustainable and the impact it can have on my daily tasks. I do what I think is appropriate, but my feeling is that, as an organization, we could work in a more sustainable way (sales clerk, R2, interview).

\section{(Mis)alignment in Key Hard Practices}

Implementation of corporate sustainability practices entails the use of key hard practices that signal a commitment to sustainability, such as procedures and standards, control and monitoring systems, and visual identity support and store layout. A common hard practice concerns the setting of specific procedures and standards aimed at coordinating the different actors within and outside the organization. Large organizations, in particular, formalize this practice because they must coordinate a large number of suppliers in different geographical areas. For example, explicit ethical codes of conduct regulate the interaction between actors and are used to personify the uniqueness of the retailer's corporate identity. Retailer 1 uses a code based on the agreements of the International Labor Organization. This company recently created a comprehensive plan that aims to strengthen the control methods used within each core business. Such a plan serves as a roadmap for the company's purchasing centers.

In keeping with the strategic focus of their own label, Retailer 2 pays close attention to the selection criteria of suppliers for the label products. Suppliers must comply with the code of ethics and follow specific guidelines. They must also adapt to adjustments that emerge subsequent to the periodic audits the company undertakes in its suppliers' facilities. As the private-label manager explained, "We are continuously improving our code of conduct and monitoring activities because we think we should keep, at any cost, the promise that the private-label products are safe, good, affordable, ethical, and ecological" (private label manager, R2, interview). These procedures and standards are not always systematically applied and inconsistencies may emerge when managing relationships with suppliers in different areas. In the case of Retailer 1, the formalization of the processes prevails over the aims of sustainability, especially when considering the social dimensions of the company's relationship with its suppliers. Frequently small-size companies do not meet the criteria and are excluded as potential suppliers.

Control and monitoring systems for the implementation of sustainability strategies are an additional critical area when connecting corporate identity and sustainability. Key performance indicators assist in the control process (Erol et al., 2009). In the case of Retailers 1, 2, and 3, these indicators are published in sustainability reports 
and play a central role in the content of external and internal communication about sustainability. Yet, companies seldom set key performance indicators, nor do they measure the impact of a sustainability orientation on the employees or other stakeholder's commitment and satisfaction. When corporate identity primarily focuses on only one of the three corporate-sustainability pillars, the initiatives become unbalanced, resulting in a less effective implementation on a holistic level. Retailer 1 initiated numerous sustainability projects to improve profitability, including shared services between core businesses, purchasing efficiency, logistics synergies, and inventory optimization. As one cashier commented,

The top management has communicated the corporate sustainability strategies and activities in the sustainability report that we received through the intranet. Yet, in the end, I do not see the effect it has on me; nobody asked me if I am happy with this, if my life has changed (and it has not). They carry on asking me to increase my speed as a cashier (cashier, R1, interview).

Hard implementation practices may also be related to visual clues, such as visual identity support and store layout. The underlying idea is to convey sustainability in the store through visual identity support systems (e.g., graphic symbols associated with loyalty programs) and store layout. The physical conditions and atmosphere in the store are important because they constitute the visible context in which corporate identity and sustainability are physically intertwined. Such conditions may entail the development of a sustainable architecture (Retailer 2); energy, water, and waste management (Retailer 1); environmental quality improvement in store fittings (Retailer 3); and production areas that demonstrate to audiences important stages of the production process (Retailer 4). Yet the physical conditions do not always translate into clear sustainability practices. The tangibles and graphic aspects related to the visual-support systems ought to be combined in a coherent and clear way. Variety in visual supports and tangibles, as in the case of Retailer 2, creates confusion in orienting the perceptions of the different stakeholders. Retailer 1 has a green area with distinctive stalls that focus on sustainability but that does not actually permeate the organizational culture. As the retailer offers a wide range of products, this initiative is considered limited. The store manager explained: "It seems to me that only a part of the store is devoted to sustainable products, while the rest is the same as in the past" (store manager, R1, interview).

\section{Managing Corporate Sustainability and Corporate Identity (Mis)Alignment}

Tensions and inconsistencies in the alignment of corporate sustainability and identity can be managed in alternative ways. The aim is to find viable solutions that capture the different meanings of sustainability to the various actors, i.e., solutions that take into account the different interpretations of a sustainable identity. According to our findings, the most effective way to successfully interlink sustainability and identity is increasingly related to the organization's ability to accept differences and to dynamically leverage the existing tensions and inconsistencies to promote debate and confrontation among the different stakeholders. A possible route to handling 
inconsistencies and dissatisfaction among employees and stakeholders is to encourage expression of ideas and opinions (Berrone et al., 2007). Such procedure may contribute to the way sustainability is strategized, managed, and maintained. For example, in the case of Retailer 1, there was the need to build the right background and environment to develop employee commitment and support for sustainability programs. Managers created innovative initiatives (titled participative innovation), based on stakeholders' contributions and ideas (in particular from employees). Retailer 4's commitment to sustainability is core to gathering all the actors involved in the various initiatives. In order to reduce the tensions and inconsistencies, specific attention is given to partner selection and training as they are an active part of the business model. A partner interviewee explained the process: "We met the criteria and, hence, we were one of the selected producers. The selection team has organized meetings to train us to learn about sales and production processes" (business partner, R4, interview).

Strong leadership is relevant to successfully setting the direction, creating the alignment, and maintaining the internal commitment (McCauley \& Van Velsor, 2004; Quinn \& Dalton, 2009) to sustainability strategies, especially when corporate identity and sustainability are misaligned. In the case of smaller companies, the development of sustainable practices that have a strong impact on the culture and behavior may be grounded in the greater power owners have compared to managers in large firms (Hamann, Habisch, \& Pechlaner, 2009). The owner's motivation towards sustainability (Jenkins, 2004) is pivotal in building a strong sustainability culture, such as in the case of Retailer 4. Larger companies, such as Retailers 1 and 2, often have a corporate-sustainability manager or similar position within the organization. Such a position has two positive implications: 1) it allows for the harmonization of corporate strategies, and sustainability strategies and practices; and 2) it signals to internal and external stakeholders the strong commitment of the company towards sustainability. Yet, if the company is fully engaged in sustainability, the presence of a corporate-sustainability manager seems to be an oxymoron. The idea is that sustainability should be a pervasive concern throughout the organization and shared by every employee. Moreover, such position may become an island when addressing sustainability issues, separated from the rest of the company. Local subsidiaries of international retail chains face this challenge. As the corporate social responsibility manager from Retailer 1 explained, "Sometimes it seems to me that I am in a very bad position: I try to develop strategies and policies in order to fulfill the sustainability aims of the global brand, but my colleagues are pressured by economic results. It's hard to be heard under such conditions" (corporate social responsibility manager, $\mathrm{R} 1$, interview).

\section{DISCUSSION}

This article offers three main theoretical contributions to the understanding of the nature of the interface between corporate sustainability and corporate identity. First, the relationship between corporate identity and corporate sustainability is symbiotic, where sustainability and identity are integrated to attain a synergetic 
balance within the organization. For corporate sustainability to become a prevailing reality in the life of an organization, there needs to be an identity platform that upholds sustainability as a business strategy and model. Alignment between corporate sustainability and identity could be created through the definition of a consistent identity that aims to develop a shared focus, over time, for the whole organization, thus, maintaining commitment by means of processes that support employee and stakeholder engagement towards sustainability. In order to successfully define corporate sustainability through a meaningful corporate identity, organizations ought to establish actions and behaviors that are aligned with their mission, goals, and objectives. Such direction needs to be associated with the introduction and diffusion of sustainability pervasiveness throughout the organization. The endeavor of interlinking corporate sustainability and identity is dynamic.

Second, building on the idea that sustainability orients an organization towards the integration of issues related to social, environmental, and economic concerns into its strategy (e.g., mission, values) and operations (Hahn et al., 2015), this study shows the combination of corporate sustainability and corporate identity at strategic and instrumental levels. A real alignment towards sustainability calls for the holistic integration of sustainability principles and practices within the organization. We uncover corporate identity as the platform from which the organization can integrate sustainability and identity through its strategic and instrumental roles. At a strategic level, corporate identity establishes the organization's character and uniqueness as reflected in its philosophy, mission, and values (He \& Balmer, 2013). Organizations with a corporate-sustainability approach base their uniqueness and differentiation (i.e., their corporate identity) on the features of their sustainability (cf. Fatma \& Rahman, 2014). This study sheds light on the development of a corporate-sustainability foundation that is rooted in identity. Sustainability morphs into the organization's intended identity and its strategic symbols, underpinning the organization's strategic logic.

The instrumental role of corporate identity is essentially captured in the articulation and dissemination of the organization's mission and values and in the tone it sets for behaviors (in particular, the behaviors of its staff and employees) (Simões et al., 2005). Corporate identity emerges from a network of relations (Balmer et al., 2007). A sustainable identity is at the core of what the organization is and does, and corporate identity plays a key role in upholding the organization's cultural orientation towards sustainability. Corporate identity can be pivotal in the operationalization and communication of sustainability strategies. It constitutes the mean that enacts sustainability strategy into practice. Corporate identity is instrumental in creating harmonized perceptions and behaviors among stakeholders in the supply chain, and in generating consistency in sustainability messages across all platforms and features of communication. Visual aspects (e.g., store layout and materials) may assist in this operationalization.

Third, the research establishes that organizations show different patterns in the interface between sustainability and identity. In particular, tensions that emerge in the alignment between both constructs reveal nuances in the embeddedness of sustainability in corporate identity at the strategic and/or operational levels. 
Three possible configurations are highlighted. The first pattern emerges when there are high levels of sustainability/identity embedment at the strategic level and when corporate sustainability initiatives are fully integrated into the operational dimensions of corporate identity (e.g., consistency in communications). Such connection makes the sustainability/identity interface transformational for the organization's culture and differentiation. The interface in its various forms and saliences becomes a way for business differentiation in the market and among stakeholders, leading to a high profile and a strong reputation. The second pattern was revealed when the alignment between corporate sustainability and corporate identity is present at the strategic level and, yet, shows inconsistencies at the operational level. When corporate sustainability is highly intertwined with corporate identity at the strategic level (morphing into a single entity), there is a high overlap, in particular when articulating the organization's mission and values. Such congruency is not necessarily reflected at more tactical levels, where consistent behaviors do not occur. As the number of sustainability initiatives increases, there is a misalignment between the guidelines for the organization's behaviors and its identity, and the key point (sustainability) is lost as employees seem to overlook part of the message. The gap in sustainability initiatives affects the company's reputation among key stakeholders. The third pattern occurs when corporate sustainability is not fully integrated into the company's identity and initiatives are fragmented or poorly communicated and managed. In such circumstances, the impact of the sustainability/identity interface is predominantly incremental, or ineffective and ambiguous. The alignment between sustainability and identity takes the form of a narrow scope of initiatives that often escapes stakeholder detection. In this context, possible outcomes are the partial or conflicting impact of sustainability on the organizational culture, ineffective differentiation among stakeholders, and a missed opportunity to enhance the company's reputation and profile.

\section{Managerial Implications and Future Research}

Our study points to general implications for managing the interface between corporate sustainability and corporate identity and to make specific recommendations to retail managers. The rationale developed in this article establishes that the probability of success for a business built on sustainability is greater when there is a fit between sustainability strategies, organizational culture (Baumgartner, 2009; Linnenluecke \& Griffiths, 2010), and company identity (Balmer et al., 2007). If properly managed, a sustainability orientation and an identity formation can align and intertwine, and can become a relevant source of competitive advantage. The integration of corporate sustainability and corporate identity will transform the market and enhance performance as stakeholders (in particular, customers) become more engaged with the company. Moreover, corporate sustainability, and/or its dimensions, is commonly considered an indicator in the measurement of corporate reputation (Sarstedt et al., 2013). The alignment between sustainability and identity can lead to a stronger sustainability position in the business environment, thus contributing to the development of a more solid reputation. 
This study suggests that managers should make sustainability part of the organization's identity at both strategic and operational levels. At a strategic level, the aim is to progressively orient corporate identity towards the integration of the three pillars of sustainability: economic, social, and environmental. The management of corporate sustainability ought to be integrated at the corporate level, in terms of the business strategy, business model, and value-generating processes and products. This integration seems to be the key dimension to reinforce corporate identity in an ethical and consistent fashion. In particular in an international context, corporate identity could assist the company's articulation and incorporation of strategic pillars of corporate sustainability. By having sustainability as an identity support, businesses set the tone for differentiation and an overall integrated market approach.

From an operational perspective, our study suggests that corporate identity could be an instrument for the implementation of corporate sustainability strategies at different levels within the organization. The use of corporate identity as a platform for the implementation of corporate sustainability allows managers to focus on the key soft and hard practices that aim to effectively articulate the translation of sustainability strategies into concrete and effective initiatives and behaviors, driving sustainability throughout the organization. Key soft practices in retailing refer to communication, education, and engagement activities. Soft dimensions should be used to leverage and align corporate identity at both corporate and functional levels, creating a widespread culture that supports sustainability decisions and motivates employees to identify with the sustainability cause. Key hard practices entail procedures and standards, control and monitoring systems, and visual identity supports and store layout. Hard practices contribute to better structuring and monitoring the processes of sustainability/identity implementation. Yet, formalization should not overtake the values that underlie sustainability issues. Because hard practices are often seen as being a top-down imposition, managers should avoid rigidity and, instead, negotiate and share an ethical code of practice with internal stakeholders. Consistency and internal coordination among practices are only possible when soft and hard practices complement each other. It should be noted that while the formalization of corporate sustainability results in supporting engagement in sustainability among employees, it might have different effects in organizations where the commitment to sustainability is mainly informal and has been embedded in the corporate culture since the company's foundation.

The process that interlinks sustainability/identity and business practices is dynamic, entailing tensions and inconsistencies between the management of the dimensions of sustainability and stakeholders' interests (e.g., the financial aims and societal targets), calling for integrative management perspectives (Hahn et al., 2015). Managers should leverage the tensions and inconsistencies that exist at the different levels of the organization by promoting a more debated and 'polyphonic' process of making the business authentically ethical. The purpose of this process should be to shape an emotionally charged corporate identity that is authentic and behaviorally based on sustainability issues. A substantive managerial approach to ethical legitimacy is especially needed when corporate identity was not originally aligned with sustainability issues and/or the company has a significant number of 
stores and employees. Inconsistencies between sustainability ideals and practices may occur making identity a socially negotiated process. When aiming at effectively transforming the corporate culture throughout the organization, it becomes important to develop real and material change in organizational processes and structures around the entity of sustainability. At the operational level, implementation strategies for corporate sustainability should involve organizational members and other stakeholders. To be truly sustainable, companies need to be able to engage internal and external stakeholders in an ongoing transformational change that must face social expectations. This process entails not only (re)framing of the company's identity at the strategic level, but also codification of the (new) identity at the operational level.

This study carries with it some limitations endemic to qualitative research. Our sample of retailers captures diverse approaches to corporate sustainability, which allowed us to gain a comprehensive view of the interface between corporate sustainability and corporate identity. Yet, future research could explore the nature of the corporate sustainability/identity relationship in other business settings, such as in manufacturing companies. Future studies may also include cross-sectional approaches that allow for the establishment of typologies of patterns and connections between corporate sustainability and corporate identity. Further, research could explore the link between these two constructs at an operational level, and consider the various hierarchies within the company and, in particular, frontline personnel. An additional avenue might consider analyzing how the link between corporate sustainability and corporate identity may be perceived and manifested among different players and stakeholders (e.g., customers, members in the supply chain) at the network level and in different business contexts (e.g., manufacturing).

\section{REFERENCES}

Abratt, R., \& Kleyn, N. 2012. Corporate identity, corporate branding and corporate reputations, reconciliation and integration. European Journal of Marketing, 46(7/8): 1048-1063.

Ahern, G. M. 2015. Imagining what underlies corporate sustainability. Journal of Management Development, 34(4): 494-504.

Albert, S., \& Whetten, D. A. 1985. Organizational identity. Research in Organizational Behavior, 7: 263-295.

Amini, M., \& Bienstock, C. C. 2014. Corporate sustainability: An integrative definition and framework to evaluate corporate practice and guide academic research. Journal of Cleaner Production, 76: 12-19.

Aras, G., \& Crowther, D. 2008. Governance and sustainability: An investigation into the relationship between corporate governance and corporate sustainability. Management Decision, 46(3): 433-448.

Arnold, D. G. 2015. Celebrating our 25th anniversary: BEQ's past, present, and future. Business Ethics Quarterly, 25(1): v-vii.

Atakan, M. S., \& Eker, T. 2007. Corporate identity of a socially responsible university: A case from the Turkish higher education sector. Journal of Business Ethics, 76(1): 55-68.

Balmer, J. M. 2011. Corporate marketing myopia and the inexorable rise of a corporate marketing logic: Perspectives from identity-based views of the firm. European Journal of Marketing, 45(9/10): 1329-1352. 
Balmer, J. M., Fukukawa, K., \& Gray, E. R. 2007. The nature and management of ethical corporate identity: A commentary on corporate identity, corporate social responsibility and ethics. Journal of Business Ethics, 76(1): 7-15.

Balmer, J. M. T., Powell, S. M., \& Greyser, S. A. 2011. Explicating ethical corporate marketing. Insights from the BP Deepwater Horizon catastrophe: The ethical brand that exploded and then imploded. Journal of Business Ethics, 102(1): 1-14.

Bansal, P. 2002. The corporate challenges of sustainable development. The Academy of Management Executive, 16(2): 122-131.

Bartels, J., Reinders, M. J., \& Van Haaster-De Winter, M. 2015. Perceived sustainability initiatives: Retail managers' intrinsic and extrinsic motives. British Food Journal, 117(6): 1720-1736.

Bartholmé, R. H., \& Melewar, T. C. 2009. Adding new dimensions to corporate identity management and corporate communications: Exploring the sensory perspective. The Marketing Review, 9(2): 155-170.

- 2011. Remodeling the corporate visual identity construct: A reference to the sensory and auditory dimension. Corporate Communications: An International Journal, 16(1): 53-64.

Baumgartner, R. J. 2009. Organizational culture and leadership: Preconditions for the development of a sustainable corporation. Sustainable Development, 17(2): 102-113.

. 2014. Managing corporate sustainability and CSR: A conceptual framework combining values, strategies, and instruments contributing to sustainable development. Corporate Social Responsibility and Environmental Management, 21(5): 258-271.

Baumgartner, R. J., \& Ebner, D. 2010. Corporate sustainability strategies: Sustainability profiles and maturity levels. Sustainable Development, 18(2): 76-89.

Bendixen, M., \& Abratt, R. 2007. Corporate identity, ethics, and reputation in supplierbuyer relationships. Journal of Business Ethics, 76(1): 69-82.

Berns, M., Townend, A., Khayat, Z., Balagopal, B., Reeves, M., Hopkins, M., \& Kruschwitz, N. 2009. The business of sustainability https://www.bcg.com/documents/file29480.pdf.

Berrone, P., Surroca, J., \& Tribó, J. A. 2007. Corporate ethical identity as a determinant of firm performance: A test of the mediating role of stakeholder satisfaction. Journal of Business Ethics, 76(1): 35-53.

Boyatzis, R. E. 1998. Transforming qualitative information: Thematic analysis and code development. Thousand Oaks, CA: Sage.

Bravo, R., Matute, J., \& Pina, J. M. 2012. Corporate social responsibility as a vehicle to reveal the corporate identity: A study focused on the websites of Spanish financial entities. Journal of Business Ethics, 107(2): 129-146.

Crews, D. E. 2010. Strategies for implementing sustainability: Five leadership challenges. SAM Advanced Management Journal, 75(2): 15-21.

De Chernatony, L. 1999. Brand management through narrowing the gap between brand identity and brand reputation. Journal of Marketing Management, 15(1-3): 157-179.

Dunphy, D., Griffiths, A., \& Benn, S. 2007. Organizational change for corporate sustainability (2nd ed.). London: Routledge.

Dutton, J. E., Dukerich, J. M., \& Harquail, C. V. 1994. Organizational images and member identification. Administrative Science Quarterly, 39: 239-263.

Erol, I., Cakar, N., Erel, D., \& Ramazan S. 2009. Sustainability in the Turkish retailing industry. Sustainable Development, 17(1): 49-67. 
Fatma, M., \& Rahman, Z. 2014. Building a corporate identity using corporate social responsibility: A website based study of Indian banks. Social Responsibility Journal, 10(4): 591-601.

Foroudi, P., Melewar, T. C., \& Gupta, S. 2014. Linking corporate logo, corporate image and reputation: An examination of consumer perception in the financial setting. Journal of Business Research, 67(11): 2269-2281.

Frandsen, S., Morsing, M., \& Vallentin, S. 2013. Adopting sustainability in the organization: Managing processes of productive loose coupling towards internal legitimacy. Journal of Management Development, 32(3): 236-246.

Gao, J., \& Bansal, P. 2013. Instrumental integrative logic in business sustainability. Journal of Business Ethics, 112(2): 241-255.

Gladwin, T. N., Kennelly, J. J., \& Krause, T. S. 1995. Shifting paradigms for sustainable development: Implications for management theory and research. Academy of Management Review, 20(4): 874-907.

Gupta, S., Czinkota, M., \& Melewar, T. C. 2013. Embedding knowledge and value of a brand into sustainability for differentiation. Journal of World Business, 48(3): 287-296.

Gupta, S., \& Kumar, V. 2013. Sustainability as corporate culture of a brand for superior performance. Journal of World Business, 48(3): 311-320.

Hahn, T., Pinkse, J., Preuss, L., \& Figge, F. 2015. Tensions in corporate sustainability: Towards an integrative framework. Journal of Business Ethics, 127(2): 297-316.

Hamann, E. M., Habisch, A., \& Pechlaner, H. 2009. Values that create value: Socially responsible business practice in SMEs: Empirical evidence from German companies. Business Ethics: A European Review, 18(1): 37-51.

Hatch, M., \& Schultz, M. 1997. Relations between organisational culture, identity and image. European Journal of Marketing, 31(5/6): 356-65.

He, H-W., \& Balmer, J. M. T. 2013. A grounded theory of the corporate identity and corporate strategy dynamic: A corporate marketing perspective. European Journal of Marketing, 47(3/4): 401-430.

Homburg, C., Klarmann, M., Reimann, M., \& Schilke, O. 2012. What drives key informant accuracy? Journal of Marketing Research, 49(4): 594-608.

Hussey, D. E. 2007. Strategic management: From theory to implementation. New Jersey: Taylor \& Francis.

Ingenhoff, D., \& Fuhrer, T. 2010. Positioning and differentiation by using brand personality attributes: Do mission and vision statements contribute to building a unique corporate identity? Corporate Communications: An International Journal, 15(1): 83-101.

Jenkins H. 2004. A critique of conventional CSR theory: An SME perspective. Journal of General Management, 29(4): 37-57.

Kapeferer, J. 1996. Strategic Brand Management. London: Kogan.

Karaosmanoglu, E., \& Melewar, T. 2006. Corporate communications, identity and image: A research agenda. Journal of Brand Management, 14(1): 196-206.

Kiron, D., Kruschwitz, N., Haanaes, K., Reeves, M., Fuisz-Kehrbach, S. K., \& Kell, G. 2015. Joining forces: Collaboration and leadership for sustainability. MIT Sloan Management Review. http://sloanreview.mit.edu/projects/joining-forces.

Kumar, V., \& Christodoulopoulou, A. 2014. Sustainability and branding: An integrated perspective. Industrial Marketing Management, 43(1): 6-15.

Lauring, J., \& Thomsen, C. 2009. Collective ideals and practices in sustainable development: Managing corporate identity. Corporate Social Responsibility and Environmental Management, 16(1): 38-47. 
Linnenluecke, M. K., \& Griffiths, A. 2010. Corporate sustainability and organizational culture. Journal of World Business, 45(4): 357-366.

Lozano, R. 2007. Collaboration as a pathway for sustainability. Sustainable Development, 15(6): 370-381.

2013. Are companies planning their organizational changes for corporate sustainability? An analysis of three case studies on resistance to change and their strategies to overcome it. Corporate Social Responsibility and Environmental Management, 20(5): 275-295.

Lubin, D. A., \& Esty, D. C. 2010. The sustainability imperative. Harvard Business Review, 88(5): 42-50.

Lynch, J. G. 1999. Theory and external validity. Journal of the Academy of Marketing Science, 27(3): 367-376.

Maletič, M., Maletič, D., Dahlgaard, J. J., Dahlgaard-Park, S. M., \& Gomišček, B. 2014. Sustainability exploration and sustainability exploitation: From a literature review towards a conceptual framework. Journal of Cleaner Production, 79: 182-194.

Marwick, N., \& Fill, C. 1997. Towards a framework for managing corporate identity. European Journal of Marketing, 31(5/6): 396-409.

McCauley, C. D., \& Van Velsor, E. (Eds.). 2004. The center for creative leadership handbook of leadership development (Vol. 29). San Francisco: John Wiley \& Sons.

Melewar, T. C., \& Saunders, J. 1999. International corporate visual identity: Standardization or localization. Journal of International Business Studies, 30(3): 583-598.

Melewar, T. C., \& Karaosmanoglu, E. 2006. Seven dimensions of corporate identity: A categorisation from the practitioners' perspectives. European Journal of Marketing, 40(7/8): 846-869.

Morsing, M. 2009. Corporate social responsibility in organizational behavior. In C. Smith \& G. Lenssen (Eds.), Mainstreaming corporate responsibility. Cases and text for integrating corporate responsibility across the business school curriculum: 438-47. London: John Wiley.

Olins, W. 1991. Corporate identity. Toledo: Thames and Hudson.

Olson, E. M., Walker, Jr., O. C., \& Ruekert, R. W. 1995. Organizing for effective new product development: The moderating role of product innovativeness. Journal of Marketing, 59(1): 48-62.

Pilditch, J. 1970. Communication by design: A study in corporate identity. London: McGraw-Hill.

Powell, S. M. 2011. The nexus between ethical corporate marketing, ethical corporate identity and corporate social responsibility: An internal organisational perspective. European Journal of Marketing, 45(9/10): 1365-1379.

Pruzan, P. 1998. From control to values-based management and accountability. Journal of Business Ethics, 17(13): 1379-1394.

Quinn, L., \& Dalton, M. 2009. Leading for sustainability: Implementing the tasks of leadership. Corporate Governance: The International Journal of Business in Society, 9(1): 21-38.

Riel, C. 1995. Principles of corporate communications. London: Prentice-Hall.

Riel, C., \& Balmer, J. 1997. Corporate identity: The concept, its measurement and management. European Journal of Marketing, 31(5/6): 340-355.

Rodrigo, P., \& Arenas, D. 2008. Do employees care about CSR programs? A typology of employees according to their attitudes. Journal of Business Ethics, 83(2): 265-283. 
Sarstedt, M., Wilczynski, P., \& Melewar, T. C. 2013. Measuring reputation in global markets-A comparison of reputation measures' convergent and criterion validities. Journal of World Business, 48(3): 329-339.

Saunders, M., Mann, R., \& Smith, R. 2008. Implementing strategic initiatives: A framework of leading practices. International Journal of Operations \& Production Management, 28: $1095-1123$.

Schmidt, K. 1995. The quest for identity. London: Cassell.

Schneider, L., Marcus Wallenburg, C., \& Fabel, S. 2014. Implementing sustainability on a corporate and a functional level: Key contingencies that influence the required coordination. International Journal of Physical Distribution \& Logistics Management, 44(6): 464-493.

Seale, C., Gobo, G., Gubrium, J. F., \& Silverman, D. (Eds.). 2004. Qualitative research practice. London: Sage.

Sebastiani, R., Corsaro, D., Montagnini, F., \& Caruana, A. 2014. Corporate sustainability in action. The Service Industries Journal, 34(7): 584-603.

Simões, C., Dibb, S., \& Fisk, R. 2005. Managing corporate identity: An internal perspective. Journal of the Academy of Marketing Science, 33(2): 153-168.

Simões, C., \& Mason, K. 2012. Informing a new business-to-business relationship: Corporate identity and the emergence of a relationship identity. European Journal of Marketing, 46(5): 684-711.

Skouloudis, A., Chymis, A., Allan, S., \& Evangelinos, K. 2014. Corporate social responsibility: A likely causality of the crisis or a potential exit strategy component? A proposition development for an economy under pressure. Social Responsibility Journal, 10(4): 737-755.

Suchman, M. C. 1995. Managing legitimacy: Strategic and institutional approaches. Academy of Management Review, 20(3): 571-610.

Turner, B. A. 1981. Some practical aspects of qualitative data analysis: One way of organising the cognitive processes associated with the generation of grounded theory. Quality And Quantity, 15(3): 225-247.

van Marrewijk, M. 2003. Concepts and definitions of CSR and corporate sustainability: Between agency and communion. Journal of Business Ethics, 44: 95-105.

Wagner, T., Bicen, P., \& Hall, Z. R. 2008. The dark side of retailing: Towards a scale of corporate social irresponsibility. International Journal of Retail \& Distribution Management, 36(2): 124-142.

WCED (World Commission on Environment and Development) 1987. Our common future. New York: Oxford University Press.

Whelan, G. 2012. The political perspective of corporate social responsibility: A critical research agenda. Business Ethics Quarterly, 22(4): 709-737.

Weiss A., Anderson, E., \& MacInnis D. 1999. Reputation management as a motivation for sales structure decisions. Journal of Marketing, 63(4): 74-89.

Wiese, A., Kellner, J., Lietke, B., Toporowski, W., \& Zielke, S. 2012. Sustainability in retailing: A summative content analysis. International Journal of Retail \& Distribution Management, 40(4): 318-335.

Windolph, S. E., Harms, D., \& Schaltegger, S. 2014. Motivations for corporate sustainability management: Contrasting survey results and implementation. Corporate Social Responsibility and Environmental Management, 21(5): 272-285.

Ytterhus, B. E., Arnestad, P., \& Lothe, S. 1999. Environmental initiatives in the retailing sector: An analysis of supply chain pressures and partnerships. Eco-Management and Auditing, 6(4): 181-188. 